\title{
MANAGERIAL ASPECTS OF STOCK WORK (ON THE EXAMPLE OF THE NATIONAL MUSEUM OF MILITARY HISTORY OF UKRAINE)
}

\author{
Minenko M. A., Minenko L. M.
}

\section{INTRODUCTION}

System organization of work of the structural units serves as a solid foundation for the successful operation of any business entity. This statement also applies to military museums, in particular the National museum of military history of Ukraine (NMMHU) - one of the leading cultural and educational institution of the Armed Forces of Ukraine. For an objective assessment of the contribution of this institution to the Ukrainian cultural and historical heritage regulatory and legal materials, internal regulations and planning documents were investigated and it made possible to identify the components of the life cycle and the peculiarities of the functioning of NMMHU at different stages of formation.

Under all circumstances, any organization (enterprise, institution) can have achievements subject to the proper level of qualification and the TOPmanagement desire to develop, the establishment of professional work of each employee, a separate functional unit and business entity as a whole. At the same time achievement of quality results by specific institutions which include museums, directly depends on the work of the unit which forms the basis of their activity and without which such institutional formations do not have any social value. Such fundamentally shaping subdivision, which under the guidance of the administration determines the main directions of development and ensures a stable functioning throughout whole life cycle, is the department of stock work of the museum. This functional direction of activity provided that if the museum institution is positioning itself as a progressive and claims to a high consumer demand is continuous, scientifically substantiated, historically objective. Exactly the stock department employees actually provide the formation of a socially perceptible cultural and anticipated content of the museum's exposition. In practice the constant replenishment of stocks with historical monuments in accordance with scientifically-defined concepts and taking into account social and state changes creates the basis for the life activity of all units. In our study, we will consider the managerial aspects of work of the department of stocks of the NMMHU in the period from 1995 to 2014 in detail. 
The source of the research became departmental normative legal documents, regulatory acts of state institutions regulating museum activities, as well as internal documents of the museum (documentary stock of the museum), scientific publications of the NMMHU.

Since the foundation of the NMMHU (1995), on questions of research and scientific direction of the stock work, as an integral part of the Ukrainian cultural-historical heritage, directly worked the head of the museum, now the Doctor of Historical Sciences, Colonel V. Karpov, as well as the research staff G. Smolianova, Z. Shulga ${ }^{1}$. Since 1999 and unchanged until 2013 during almost all years of activity of the Museum of the Armed Forces of independent Ukraine, this direction was headed by the chief custodian of stocks Zhanna Denysiuk ${ }^{2}$. By the profession, she is a culturologist, graduated from the Kyiv National University of Culture and Arts. In 2018, she received a scientific degree of Doctor of Cultural Studies. Today she works as the head of the scientific and publishing department of the National academy of managerial staff of culture and arts. Zh. Denysiuk is the author of two monographs and over 80 scientific works. Among her scientific interests are: the actual problems of modern culture, communication, mass culture, museology.

Under the guidance of $\mathrm{Zh}$. Denysiuk, the department of stock work of the NMMHU provided the main directions for scientific-research, expositional, exhibition and excursion work. In the works of the scholar methodology for the organization of the stock work of the military museums is disclosed, what is published in the specialized magazines of the Ministry of Education of Ukraine and on the pages of periodicals, in particular, "Military Museum" and "Military Historical Almanac" 3 . Other museum employees in their researches also revealed some components of the technology of stock work. Thus, stock acquisition of the NMMHU and its branches highlighted V. Davydiuk, L.Tarasenko ${ }^{4}$. The methodology of organizing the exposition

${ }^{1}$ Карпов В. Музейна справа у Збройних Силах України (1996-2006). Київ : ЦМЗСУ ; МДФ «Українська хата», 2007. 96 с.

2 Міненко Л. Віктор Карпов - організатор першого військово-історичного музею Збройних Сил України. Воєнно-історичний вісник. 2017. № 4(26). С. 69-78.

${ }^{3}$ Карпов В. (відп. ред.). Виставка «Військова символіка України» в ЦМЗСУ. Військово-історичний альманах. 2007. № 2 (15), 1 обкл; Денисюк Ж. Комплектування фондів військового музею. Військовий музей. 2004. № 5. С. 251257; Її ж: Комплектування фондів та наукові дослідження музейних предметів. Украӥнський військовий музей. 2009. № 1. С. 23-27; Ії̈ ж: Музейний предмет як джерело військової історії. Украӥнський військовий музей. 2010. № 2. С. 28-31.

Давидюк В. Основні напрями науково-фондової роботи ЦМЗСУ 3 комплектування музейного зібрання. Військовий музей. 2007. № 8. С. 183-189; Тарасенко Л. Комплектування фондів - один із головних напрямів формування джерельної бази музею РВСП. Військовий музей. 2006. № 7. С. 161-166. 
and conducting thematic exhibitions at the NMMHU and its branches was described by N. Sedak ${ }^{5}$ and I. Yefimova ${ }^{6}$. Aspects of the work of the stock department in the part of conducting an examination and organization of search work are analyzed in the works of S. Rudenko ${ }^{7}$ and T. Butko . Despite the significant role in the establishment and development of a cultural and educational institution the work of the research department of the stock work of the National museum of military history of Ukraine has not been thoroughly investigated.

The publication's purpose is study of the peculiarities of managerial aspects of stock work on the example of the National museum of military history of Ukraine. For a complex research, we propose to solve the following tasks:

- to define the stages of the life cycle of the NMMHU in the period from 1995 to 2014;

- to group the types of activities of the military museum in terms of stages of its life cycle;

- to study the peculiarities of the functioning of the stock work department of the NMMHU in order to assess its place and role in the process of formation of the Ukrainian cultural-historical heritage.

\section{Stages of development and activities of the National museum of military history of Ukraine}

The classic life cycle of any organization (enterprise, institution) presents five (six) major development phases, each has certain goals, features, guidance style, task, and organization of work. In particular, M. Nebava and O. Ratushniak name five stages: origin, creation, growth, maturity, decline ${ }^{9}$. H. Monastyrskyi in his turn identified six stages: birth, childhood, youth, maturity, aging and rebirth ${ }^{10}$. By transforming these approaches to the conditions of functioning of a museum institution today, our vision of the

${ }^{5}$ Седак Н., Денисюк Ж. Методика організації та проведення тематичних виставок у військово-історичному музеї (з практики роботи ЦМЗСУ). Військовий музей. 2001. № 2. С. 102-112.

${ }^{6}$ Єфімова І. Виставка «Солдат і зброя». Військово-історичний альманах. 2007. № 1 (14). С. 159-160.

${ }^{7}$ Руденко С. Грошова оцінка музейних предметів, що належать до зібрання НВІМУ. Украӥнський військовий музей. 2010. № 2. С. 11-14.

${ }^{8}$ Бутко Т. Аспекти пошукової роботи ЦМЗСУ. Украӥнський військовий музей. 2009. № 1. С. 28-30.

9 Небава М., Ратушняк О. Менеджмент організацій і адміністрування. Частина 1 : навчальний посібник. Вінниця : ВНТУ, 2012. 105 с.

${ }^{10}$ Монастирський Г. Теорія організації : підруч. Тернопіль : ТНЕУ, 2014. $288 \mathrm{c}$. 
content of the stages of the life cycle of the NMMHU can be represented as: origin, creation, growth, maturity, uncertain transformation, the beginning of aging (fig. 1).

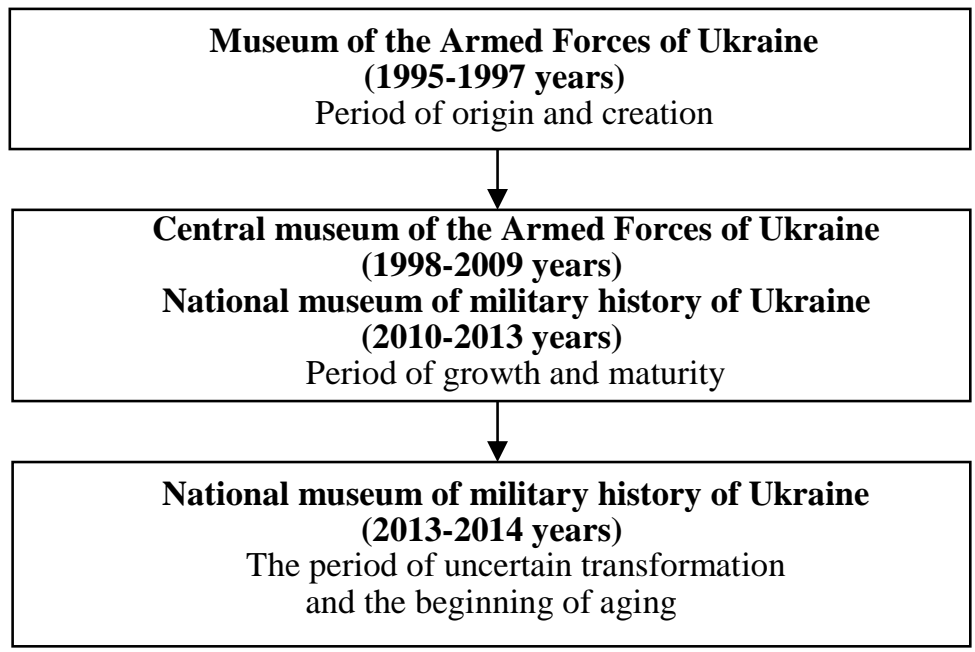

Fig. 1. Stages of the life cycle of NMMHU in the period from 1995 to 2014 years (formed by authors using ${ }^{11}$ )

As a direct participant in the process L. Minenko argues that under the leadership of V. Karpov on January 1, 2013 NMMHU was in a state of maturity and focused on the objective and scientific formation of collection as an integral part of the Ukrainian cultural-historical heritage, and further development.

It is known from practice that the maturity of any institution depends on available resources, personal characteristics and management capabilities, professional potential of the formed staff. Such stage of the life cycle as aging, especially for the museum, usually occurs during the period of transgression (the change of value orientations in the state, the replacement of the directorate). Transgression caused the uncertain transformation and

11 Небава М., Ратушняк О. Менеджмент організацій і адміністрування. Частина 1 : навчальний посібник. Вінниця : ВНТУ, 2012. 105 с.

Монастирський Г. Теорія організації : підруч. Тернопіль : ТНЕУ, 2014. 288 с.

Міненко Л. Віктор Карпов - організатор першого військово-історичного музею Збройних Сил України. Воєнно-історичний вісник. 2017. №4(26). С. 69-78. 
the beginning of aging of the NMMHU. In fact, from the middle of 2013 under the influence of organizational and qualification abilities of the new head and his state's preferences concerning the formation of the cultural and historical heritage of independent Ukraine sharp functional changes in the activity of the NMMHU began. Today transgression phenomena continue to influence the state of the museum institution. Nevertheless, according to our belief the NMMHU should function, fulfill its social mission, and be an institution of national-cultural dignity and patriotic education.

The analyzed internal regulations and reporting documents of the NMMHU gave an opportunity to group the types of activities carried out during each stage of the life cycle of the museum as follows (table 1).

Table 1

Grouping of types of activities of the National museum of military history of Ukraine in terms of certain stages of its life cycle from 1995 to 2014 years*

\begin{tabular}{|c|c|}
\hline Group & Types of activity \\
\hline \multicolumn{2}{|c|}{$\begin{array}{l}\text { Museum of the Armed Forces of Ukraine (1995-1997 years) } \\
\text { Period of origin and creation }\end{array}$} \\
\hline $\begin{array}{l}\text { The activity is aimed to } \\
\text { create a scientific center for } \\
\text { the study of military history } \\
\text { and the systematization of } \\
\text { military museum work in } \\
\text { Ukraine as a national } \\
\text { instrument of patriotic } \\
\text { education. }\end{array}$ & $\begin{array}{l}\text { - definition of the mission, goals, functions } \\
\text { and strategy of the museum development; } \\
\text { administrative and normative activities of the } \\
\text { head and scientific museum staff; } \\
- \text { continuous securing museum's stocks; } \\
- \text { establishment of proper museum and } \\
\text { scientific } \\
\text { accounting of stocks; } \\
-\quad \text { creating an exposition of the museum; } \\
- \text { excursion (educational) activity }\end{array}$ \\
\hline \multicolumn{2}{|c|}{$\begin{array}{l}\text { Central museum of the Armed Forces of Ukraine (1998-2009 years) } \\
\text { National museum of military history of Ukraine (2010-2013 years) } \\
\text { Period of growth and maturity }\end{array}$} \\
\hline $\begin{array}{l}\text { The activity is aimed at } \\
\text { systematic, scientific and } \\
\text { methodological functioning } \\
\text { of the museum, the } \\
\text { formation of national } \\
\text { dignity and patriotism }\end{array}$ & $\begin{array}{l}\text { - military patriotic education of visitors } \\
\text { through conducting of thematic tours, lessons } \\
\text { "Protecting the Motherland", providing } \\
\text { opportunities to conduct public events with the aim } \\
\text { of forming national dignity and patriotism; } \\
- \text { creation, debugging of activity, } \\
\text { development of branches of the NMMHU; } \\
- \text { creation of a network of military museums } \\
\text { of the Armed Forces, scientific and methodological } \\
\text { guidance on their activities; } \\
- \text { working of scientific professional } \\
\text { achievements of management and scientific staff, }\end{array}$ \\
\hline
\end{tabular}




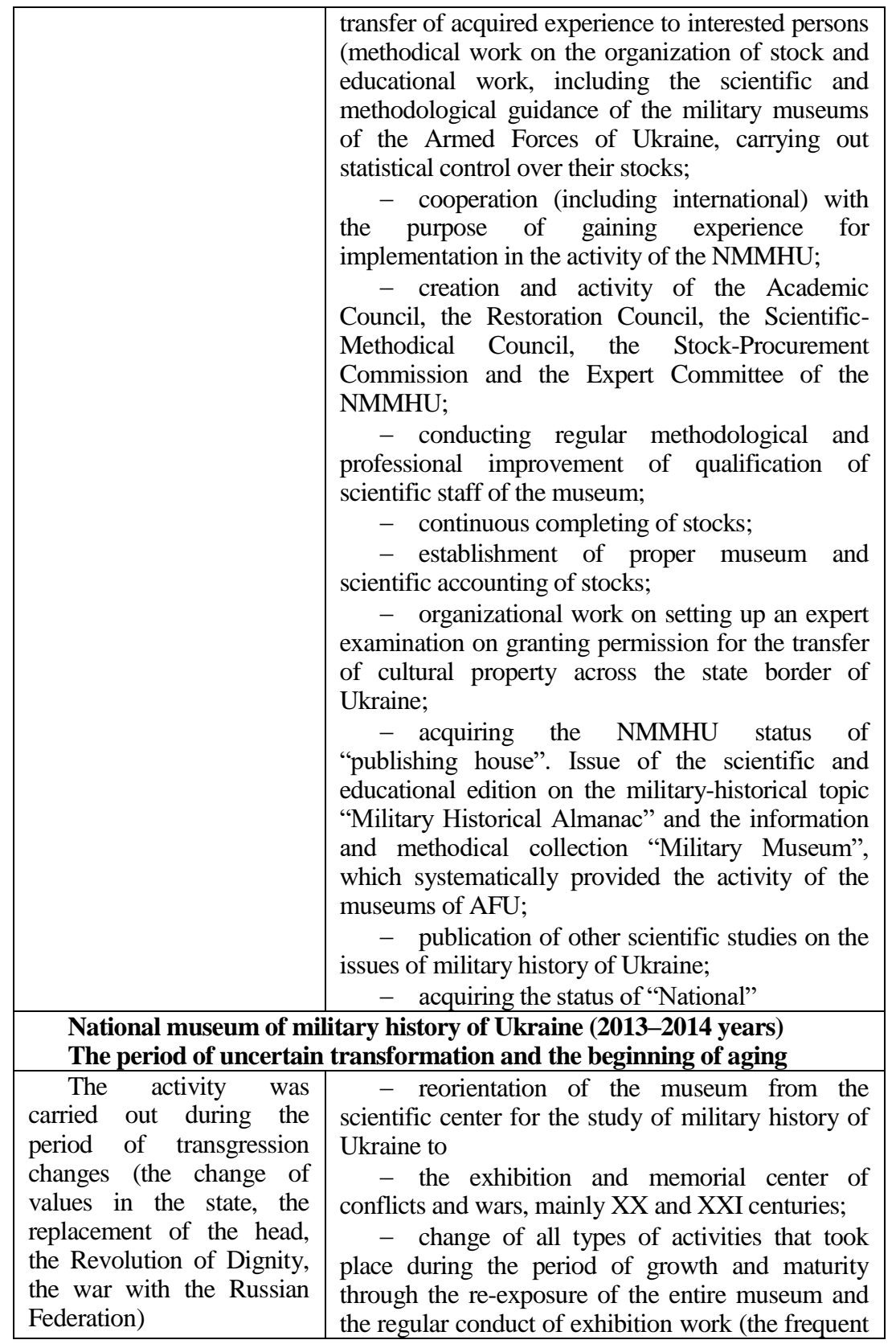




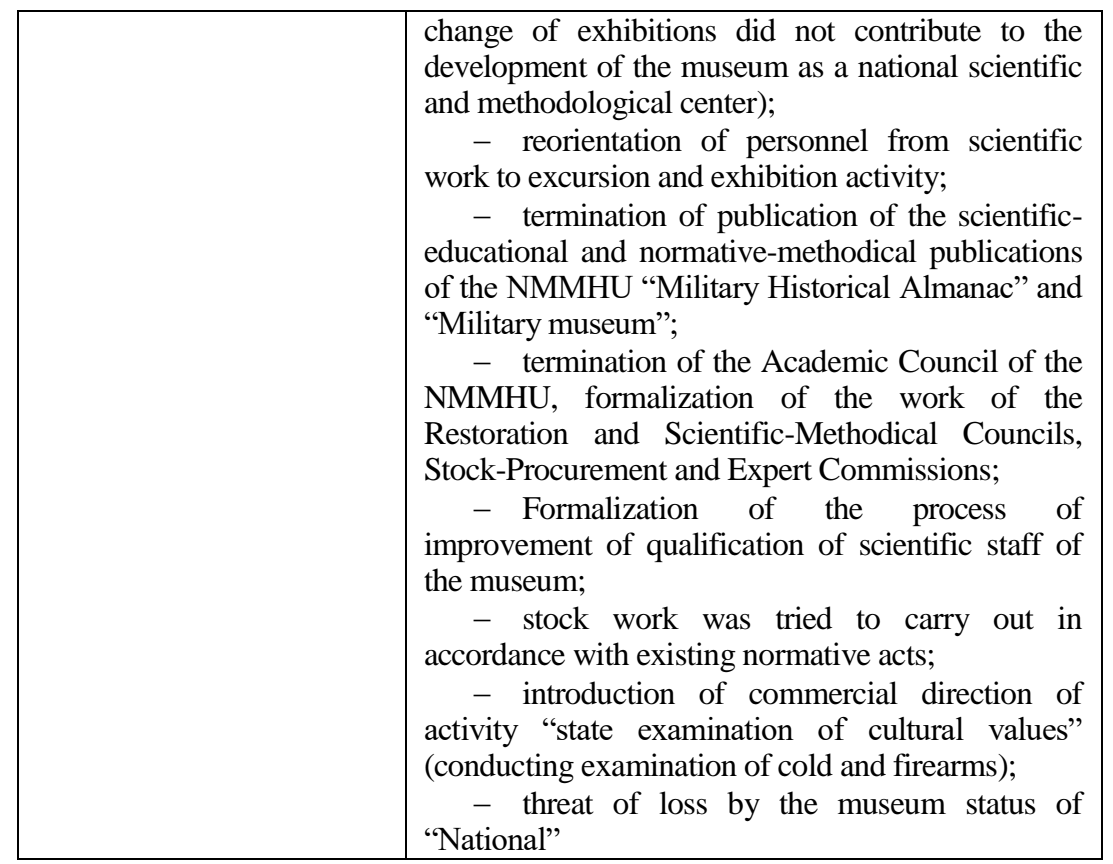

* Source: formed by the authors according to the results of the study

As we can see from the table during the period of uncertain transformation and the beginning of aging significant changes happened that influenced the work of all units of the NMMHU which ensured the quality of the museum product and services. In fact, with the change of guidance and development strategy was eliminated the place and role of the scientific unit of the stock work of the National museum of military history of Ukraine, especially in terms of preservation and integral system formation of the Ukrainian cultural-historical heritage.

\section{Stock work of the National museum of military history of Ukraine}

Z. Denysiuk in her studies on the stock activity of the military museum pointed: "The museum's stocks are a collection of materials that have been submitted to the museum for permanent storage in accordance with the adopted rules (instructions). They are the basis for all types of museum activities and are used as a source base" ${ }^{\prime 12}$. According to the Statute of the

12 Quoted for: Денисюк Ж. Комплектування фондів військового музею. Військовий музей. 2004. № 5. С. 251-257. 
NMMHU stocks are divided into: main; scientific-auxiliary; exchange. The main stock of the museum includes real objects that have historical, scientific, artistic value and reflect the military history of Ukraine. These are real, written, pictorial, cinema, video and photo materials, phonograms. Including military flags, standards, pennants, weapons, military equipment, awards, decorations, things of military everyday life, personal belongings of soldiers, fighting trophies and other museum items characterizing the development of military history. The scientific-auxiliary stock includes materials made by the museum for the needs of the exposition (schemes, maps, mock-ups, models), as well as various copies of photographs, documents and other subjects. That are materials that help to study the primary sources. The exchange stock includes non-profiled museum items and doublet copies which are counted in more than five copies ${ }^{13}$.

After analyzing the internal regulations, planning and reporting documents of the NMMHU for the periods of origin, creation, growth and maturity the authors investigated the transformation of the titles of the department of stock work. Thus, from 1996 to 2000 the department of stock has been working, from 2001 to 2011 has been functioning a laboratory of scientific-research works on the research of stock work problems, from 2011 to 2014 the scientific division of the stock work worked. All activity of the museum was carried out in accordance with the annual perspective work plan. From the very beginning this document contained the main tasks of the museum and its branches for a year by directions: information-museum activity, scientific-research activity, stock work. Subsequently other directions were added: methodical work, international activity, administrative and economic activity. At the same time the section of the annual plan of the museum "Stock work" at the initial stage of activity (in particular in 2000) contained two divisions:

- completing of stocks (in accordance with the exposition and exhibition activity of the main museum and its branches, including conducting of search works, expeditions);

13 Про перейменування Центрального музею Збройних Сил України в Національний військово-історичний музей України та затвердження його Статуту : Наказ Міністерства оборони України від 16.07.2010 р. № 374. ГДАМОУ (Галуз. держ. архів Міністерства оборони України). Ф. 3697. Оп. 1П. Спр. 60. Арк. 59-76. 
- accounting and systematization of stocks (statistical reporting, systematization and cataloging of stocks, works on saving stocks, inventory, etc.) $)^{14}$.

With the increase of the volume of works in the process of museum activity, the section of the annual plan "Stock work" expanded and improved. In 2013 it consisted of five divisions ${ }^{15}$ :

1. Scientific acquisition of funds by museum collections and thematic sections. Completion with materials from military units and disbanded institutions. Conducting search-and-reconnaissance expeditions in places of driving battles of fighting troops, military training and other military maneuvers in order to identify objects of historical value. Acquisition of the scientific archive and library of the museum. Work of the stock-purchase commission (consideration and adoption of new revenues to museum stocks; purchasing of museum objects; conducting scientific expertise and determining the estimated value of museum objects; analysis of the quality of paperwork with accounting documents).

2. Accounting of the museum stocks (submission of statistical report in the form of 8-nk, analysis of the receipt and movement of museum stocks for the year, paperwork of the current documentation of acceptance and issue of exhibits, accounting of exhibits of the main, scientific-auxiliary and library stocks). Scientific processing and systematization of museum stocks (inventory of items of the main stock (by groups of storage); certification of objects of the main stock with the provision of photographic fixation of objects; creation of electronic passports, creation of scientific information catalogs of storage groups of monuments: a weapons stock, awards and honors, stock of flags, an archeology stock; adding additions to the systematic and alphabetical catalogs of the library stock; drafting of additions to thematic-exposition plans of the museum exposition). Preparation of the annual bibliographic index of the military press review for the year. Scientific inventory of museum stocks.

3. Organization of conducting of scientific expertise of subjects of military-historical themes (including by appeals from organizations).

4. Provision of material and technical conditions for the safe exposition and storage of museum items. Organization of permanent monitoring of the stage of preservation of museum objects, restoration and conservation of museum objects, prevention of their damage and destruction. Equipment of

14 Перспективний План роботи Центрального музею Збройних Сил України на 2000 рік. Архів НВІМУ. Док. фонд. 9 арк.

15 Перспективний План роботи НВІМУ та його філій на 2013 рік. 2013 р. Архів НВIМУ. Київ. Док. фонд. 67 арк. 
the stockstorages with special furniture and equipment according to storage groups.

5. Cooperation with the press service of the Ministry of Defense of Ukraine on the collection of materials about the activity of the Armed Forces of Ukraine.

At the end of the year each department reported on the activity carried out, what reflected in the annual report of the museum. The latter contained all sections of the annual plan and was compiled according to the requirements of scientific work. All schedule-reporting and office documentation of the main museum and its branches was completed and transferred for preserving to the museum's archive. It is worth noting that in the period from 1998 to the middle of 2013, due to the understanding of place and role, the stock work of the NMMHU was systematically and professionally improved and acquired qualitatively modern features. From the middle of 2013, in the activity of the state, and then of the museum began the transgression phenomena, which led to uncertain transformation and, in our opinion, began the beginning of its aging.

\section{Managerial aspects of the stock work of the National museum of military history of Ukraine}

In the context of these events, we describe the managerial aspects of the stock work of the National museum of military history of Ukraine in more detail. This type of work as a scientific acquisition of stocks we will consider in a separate study. In the article we will analyze the work of the department in terms of accounting of stocks, organization of conducting scientific expertise, provision of material and technical conditions for the safe exposition and storage of museum objects, cooperation with the press service of the Ministry of Defense of Ukraine.

According to the "Instruction on museum accounting, storage and use of the monuments of the state part of the museum stock of Ukraine" from September 29, 2011, the accounting of museum objects and collections at the NMMHU is intended to ensure the process of systematic data collection and registration of the necessary information (low-down) about the monuments that are national and cultural property. The accounting of museum objects and collections involves two stages ${ }^{16}$ :

16 Протокол Науково-методичної ради НВІМУ щодо затвердження «Інструкції з музейного обліку, зберігання та використання пам'яток державної частини музейного фонду України». 29.09.2011 p. Архів НВIMУ. Київ. Док. фонд. 74 арк. 
- primary registration - accounting of items that arrived at the museum. Fixation of the main distinctive features of objects in the acts of acceptance, the book of accounting of incomes (of main stock) or the book of accounting of scientific and support materials on the basis of the results of their preliminary study (primary attribution);

- scientific inventory - accounting of the main stock, which involves fixing the results of expanded attribution of museum items in inventory and special inventory books for the purpose of legal consolidation of objects in a certain museum collection and the protection of scientific data on objects.

The main documents for the accounting of museum objects and collections are acts of acceptance and issue, books of incomes, inventory books, special inventory books. The indicated books were numbered, laced, sealed with seals of the museum, certified by the signatures of the head of the museum and the main custodian of the stocks. Paperwork of accounting documentation with the help of automated information systems provided for the mandatory possession of a handwritten copy of the book of incomes.

During the museum's activity, annually, the main custodian of stocks made a description of the stock-accounting documentation and submitted to the State Statistics Service of Ukraine an annual report on the form No. 8-NK, containing consolidated data on the movement of museum objects (new incomes and those issued for permanent storage). In addition, the NMMHU annually had to provide information on changes in the composition and volume of stocks, museum maps and archive descriptions to the Branch State Archive of the Ministry of Defense of Ukraine. Besides, the report on the presence and movement of missile technology and ammunition, artillery and small arms was provided to the Central Missile and Artillery Department of the Armed Forces of Ukraine, the Material Service of Rear and the Service of Engineer Forces and Radiation, Chemical and Biological Defense Forces ${ }^{17}$.

In 1995 the workers of the newly created Museum of the Armed Forces of Ukraine carried out the initial registration of museum items inherited from the Museum of the History of Forces of the Red Army of the Kiev Military District. It should be noted that at this stage there was a shortage of museum specialists. Museum items have passed only the primary registration. In spite of everything, at the time of the birth and creation of the museum (1995-

17 Звіт про діяльність Національного військово-історичного музею України (HBIMУ) за 2010 рік. 2010 р. Архів НВIMУ. Київ. Док. фонд. 85 арк.; Там само за 2011 рік. 69 с.; Там само за 2012 рік. 55 с.; Там само за 2013 рік. 113 с.; Протокол Науково-методичної ради НВІМУ щодо затвердження «Інструкції 3 музейного обліку, зберігання та використання пам'яток державної частини музейного фонду України». 74 арк. 
7 years), the head of the museum V. Karpov and the scientific workers began the professional establishment of the functioning of accounting system of objects that arrived at the museum. In fact, accounting was limited to primary records and required the introduction of a scientific description of subjects $^{18}$. In 1998 a scientific inventory of weapons was set up which resulted in the allocation of military equipment and armaments stock in the main stock. The main supplier of this group of items was the Main Missile and Artillery Department of the Ministry of Defense of Ukraine ${ }^{19}$.

Since 1999, with the advent of the head of the department of stock work Denysiuk Zhanna, the process of the systematization of incomes, their accounting and inventory, which was carried out in accordance with the requirements of the classification of museum stocks has been improved. A system of accounting for incomes was introduced, inventory cards were issued on exhibits of weapons, awards, separate exhibits of a real stock and the conditions for storage of exhibits in the museum's stocks have been established $^{20}$.

In 2000 the stocks of the museum separately allocated a stock of awards: all the honors and awards are placed on special plates and is equipped a place for their permanent storage ${ }^{21}$. Since March 2011, after examination by the State Probation Service of Ukraine of the stock of awards and breastplates regarding the probable content of precious metals, an internal Instruction on the accounting and storage of museum items at the part of the storage and accounting of objects containing precious metals in accordance with the requirements was revised. "Instructions on the accounting of museum values of precious metals and precious stones contained in state museums of the USSR", approved by the Order of the Ministry of Culture of December 15,1987 No. $513^{22}$. The inventory of museum items of the stock of awards has been carried out. In connection with the development of

18 Звіт про діяльність Музею Збройних Сил України (МЗСУ) за 1997 рік. 1997 р. Архів НBIMУ (Архів Національного військово-історичного музею України). Київ. Док. фонд. 3 арк.

19 Там само за 1998 рік. 4 арк.

20 Звіт про діяльність Центрального музею Збройних Сил України (ЦМЗСУ) за 1999 рік. 1999 р. Архів НВIMУ. Київ. Док. фонд. 4 арк.

${ }^{21}$ Карпов В. Діяльність ЦМЗСУ у 2000 році. Військовий музей. 2001. № 2. C. 90-101.

22 Об инструкции по учету и хранению музейных ценностей из драгоценных металлов и драгоценных камней, находящихся в государственных музеях СССР : Приказ Министерства культуры СССР от 15.12.1987 г. № 513. URL: http://ppt.ru/docs/prikaz/minkultury-sssr/n-513-69255 (дата обращения: 26.12.2018 г.). 
digital technologies, photo fixation of awards was made to create a database in digital format, inventory cards and scientific passports were finalized ${ }^{23}$.

Besides, in 2000 the documentary stock was systematized and accordingly placed by the chronological-thematic structure (and the original documents and copies are separated). Also highlighted exchange and scientific-auxiliary photo stocks. They are ordered by subject and chronology. At the same period, employees of the department of stocks: started work on studying materials of periodicals and the creation of bibliographic manuals for internal use; a bibliographic index has been developed and prepared "A thematic review of military-historical magazines that are available in the library of the museum" 24 .

In 2002, Zh. Denysiuk developed a sample of the unified passport of the museum's monuments of the main stock $^{25}$. This form of accounting was mandatory for all branches of the museum and recommended for use in the military museums of the AFU. The certification of museum objects of the main stock in future should have become basic for the creation of electronic automated information retrieval systems ${ }^{26}$. At the same time, since 2002 (the entry into force of the Order of the MDU of March 6, 2002, No. 95), the Central Museum of the Armed Forces of Ukraine began to conduct scientific and methodological guidance of museums and rooms of combat and labor glory of the AFU. Employees of the scientific department of stock work together with the museum's chief constantly provided methodological recommendations on requests.

In 2004, work was completed on the issue of passports for objects of military equipment and weapons, which were available at this time. To improve work with citizens who help to complete museum stocks and transfer items for purchase, a special card file with the address data of such persons was issued. For the purpose of the most complete study of the movement of museum stocks and their accounting, keeping of a special account book was implemented, to which certain items were published that were issued as to scientific workers of museum, as well as to other citizens or scientific institutions, according to their requests, for scientific study and

23 Звіт про діяльність НВІМУ за 2011 рік. 2011 р. Архів НВIМУ. Київ. Док. фонд. 69 с.

${ }^{24}$ Карпов В. Діяльність ЦМЗСУ у 2000 році. С. 90-101.

25 Він же. Діяльність ЦМЗСУ у 2002 році. Військовий музей. 2003. № 4. C. $105-120$.

${ }^{26}$ Він же. Діяльність ЦМЗСУ у 2003 році. Військовий музей. 2004. № 5. C. $179-200$. 
analysis or for temporary storage for the purpose of exhibiting with obligatory return $^{27}$.

In 2005, after inventory of the stock of flags (combat, transitional, state flags and pennants) into a separate storage group, a stock of flags was allocated from the real stock and set up a separate inventory book ${ }^{28}$.

In addition to ensuring the stock work of the Main Museum of AFU, the department staff provided constant support and control over the work of the branches of the NMMHU. Stocks of branches were included in the list of general stocks of the museum. As of January 1, 2014, the NMMHU consisted of five branches: Volyn regional museum of Ukrainian troops and military equipment (1999 entry into the structure then Central museum of the Armed Forces of Ukraine); Museum of Strategic Missile Forces (2000); Central Military Naval Museum of Ukraine (2003 and 2009 years); Museum "Heroes of the Dnieper" (2010); Memorial complex "In memory of the Heroes of Kruty" $(2010)^{29}$.

It should be emphasized that during the investigated period, to carry out the entire volume of stock works was rather difficult. Exactly at the stages of the birth, creation and growth the level of personnel support was minimal. For example, in 2006 the provision of the implementation of the main tasks and directions of the stock work was carried out by 2 staff members ${ }^{30}$. Subsequently, the situation improved as well, at the moment when the museum received the status of "National" (2010), the museum already employed 12 full-time specialists, including 2 candidates of sciences and 3 scholars who were also involved in the work of the stock department ${ }^{31}$. The presence of a highly skilled staff contributed to the fact that since 2010 systematic methodological and practical assistance has been providing in organizing and staging on a centralized account of the objects of the museum stock for all branches and museums of the Armed Forces of Ukraine.

27 Скрябін О. Звіт ЦМЗСУ про діяльність у 2004 році. Військовий музей. 2005. № 6. С. 159-187.

${ }^{28}$ Він же. Звіт ЦМЗСУ про діяльність у 2005 році. Військовий музей. 2006. № 7. С. 167-199.

29 Про перейменування Центрального музею Збройних Сил України в Національний військово-історичний музей України та затвердження його Статуту : Наказ Міністерства оборони України від 16.07.2010 р. № 374. ГДАМОУ (Галуз. держ. архів Міністерства оборони України). Ф. 3697. Оп. 1П. Спр. 60. Арк. 59-76.

${ }^{30}$ Скрябін О. Звіт ЦМЗСУ про діяльність у 2006 році. Військовий музей. 2007. № 8. С. 204-250.

31 Звіт про діяльність НВІМУ за 2010 рік. 2010 р. Архів НВIMУ. Київ. Док. фонд. 85 арк. 
Regarding the organization of scientific expertise, it should be noted: all items of the main stock that came to the NMMHU in order to determine the historical value and inclusion in the Museum Stock of Ukraine passed such a procedure. This is defined in Art. 2 of the Law of Ukraine "On Museums and Museum Affairs" of June 29, 1995, No. 249/95-VR ${ }^{32}$. At the same time, by the Resolution of the Cabinet of Ministers of Ukraine "On Approval of the Regulation on the Museum Stock of Ukraine" of July 20, 2000 No. 1147 was approved, that conducting an examination of cultural values, in particular, for the purpose of including them in the museum collection, is carried out by the permanent consultative and advisory body of the museum - the Stock-Procurement Commission ${ }^{33}$. Estimating the cost of items and the determination of their insurance value was carried out in accordance with the Order of the Ministry of Culture and Arts of Ukraine "About approval of the Instruction on the procedure for determining the estimated and insurance value of memorials of the Museum Stock of Ukraine" dated July 13, 1998, No. $325^{34}$. At the time of accepting museum items for permanent storage, a copy of the act of admission and expert opinion of the scientific expertise on the objects of the main stock, reviewed by the Stock-Procurement Committee of the branch, as well as a copy of the protocol, were sent to the Main Museum of the AFU. After approval of the expert opinion and the decision of the Stock-Procurement Committee of the Main Museum of the AFU on the assignment of items to the museum stock and a specific group of storage, these items were registered in the stockaccounting documentation and were issued to materially responsible storage to the branch ${ }^{35}$. If an item that was submitted for consideration to the Main

32 Про музеї та музейну справу : Закон України від 29.06.1995 № 249/95-BР. Дата оновлення: 02.10.2018. URL: http://zakon.rada.gov.ua/laws/show/249/95$\% \mathrm{D} 0 \% \mathrm{~B} 2 \% \mathrm{D} 1 \% 80$ (дата звернення: 26.12.2018).

33 Про затвердження Положення про Музейний фонд України : Постанова Кабінету Міністрів України від 20.07.2000 р. № 1147. Дата оновлення: 23.03.2014. URL: http://zakon.rada.gov.ua/laws/show/1147-2000-\%D0\%ВF (26.12.2018 p.).

34 Про затвердження Інструкції про порядок визначення оціночної та страхової вартості пам'яток Музейного фонду України : Наказ Міністерства культури і мистецтв України від 13.07.1998 р. № 325. Дата оновлення: 17.10.2002 p. URL: http://zakon.rada.gov.ua/laws/show/z0496-98 (дата звернення: 26.12.2018 p.).

35 Протокол Науково-методичної ради НВІМУ щодо затвердження «Інструкції з музейного обліку, зберігання та використання пам'яток державної частини музейного фонду України». 29.09.2011 р. Архів НВIMУ. Київ. Док. фонд. 74 арк. 
Museum or branch required special attribution, experts in the relevant branches of knowledge were brought in for the examination.

In 2013, according to the Order of the Ministry of Culture and Arts of Ukraine dated November 15, 2002 No. 647 "On Approval of the List of state institutions, cultural institutions, and other organizations which grant the right to conduct a state examination of cultural values", The National museum of military history of Ukraine received the right to carry out a scientific examination of cold and firearms. Since October 2013, the museum has opened a commercial direction of activity "state expert examination of cultural values" for collectors and other connoisseurs of antique weapons. The museum signed an agreement on cooperation with the State Scientific-Research and Expert-Forensic Center of the Ministry of Internal Affairs of Ukraine, according to which objects of historical and cultural value and seized by the bodies of the Ministry of Internal Affairs of Ukraine have to be transferred to the stocks of the National museum of military history of Ukraine ${ }^{36}$.

According to Art. 21 of the Law of Ukraine "About museums and museum affairs" each of the groups of museum items requires proper storage conditions (Verkhovna Rada Ukrainy, 1995). The main conditions for ensuring the material and technical conditions for the safe exposition and storage of museum items is the proper storage of museum objects and collections, the satisfactory condition of the museum as a whole, engineering systems and microclimate maintenance ${ }^{37}$.

From the first days of the museum's existence, the head of the museum V. Karpov was in charge of this issue, and later - full-time scientific worker assigned to the direction of the stock work. Since 1999, proper conditions have been created for the storage of exhibits in the museum's stocks. In particular, the premises are allocated for the library and archive of the museum, the storage of real, artistic, awards and other stocks is provided. Is defined the schedule and procedure for implementation in the museum of preventive measures for the preservation of real stock collections, taking into account the norms and features of storage ${ }^{38}$. By 2010 stock collections were kept in proper conditions, in appropriately secured premises. However, since that time work of the stock department of the museum was significantly

36 Звіт про діяльність НВІМУ за 2013 рік. 2013 р. Архів НВІМУ. Київ. Док. фонд. 113 с.

37 Протокол Науково-методичної ради НВІМУ щодо затвердження «Інструкції з музейного обліку, зберігання та використання пам'яток державної частини музейного фонду України». 29.09.2011 р. Архів НВIMУ. Київ. Док. фонд. 74 арк.

38 Звіт про діяльність ЦМЗСУ за 1999 рік. 1999 р. Архів НВІМУ. Київ. Док. фонд. 4 арк. 
complicated. Thus, according to the Directive of the Minister of Defense of Ukraine No. D 322/1/10 DSC of September 30, 2010, the forced reorganization of stocks was carried out. Proper by conditions of storage and correspondingly fixed premises of the stocks of the National museum of military history of Ukraine transferred to the Department of press and media relations of the Ministry of Defense of Ukraine ${ }^{39}$. Besides, in 2011 the reattachment of the part of premises of the Central House of Officers of the Armed Forces of Ukraine to the National museum of military history of Ukraine took place, which also did not facilitate the storage of stocks and led to the need to change their place of residence ${ }^{40}$. In fact, since 2010 , the lion's share of the resources of the museum was aimed not at providing scientific museum stock work, but for repairs, purchases of special furniture and the design of new proper premises for the work of the scientific stock department.

One more type of activity of the stock department is cooperation with the press service of the Ministry of Defense of Ukraine on the collection of materials on the development of the Armed Forces of independent Ukraine and coverage in media of current work of the NMMHU ${ }^{4}$. From 1997 to 2014, employees held more than 80 exhibitions, both stationary and mobile ${ }^{42}$. Among them a significant number was devoted to actual socialstate events and honoring the memory of heroic personalities of the Armed Forces of Ukraine. That is why the main assistance to the museum from the press service of the Ministry of Defense of Ukraine was the provision of museum items and photos. Besides, the press service of the Ministry of Defense of Ukraine in the press and on television covered the activities of the NMMHU of military-patriotic education and the formation of national dignity. Thanks to such publications appeared an interest in the activity of the museum institution among the citizens, and in particular - teachers of pre-conscription training of schools in Kyiv. Thus, the secondary school № 159 of the Solomianskyi district of the capital has ordered and installed a

39 Звіт про діяльність НВІМУ за 2010 рік. 2010 р. Архів НВІМУ. Київ. Док. фонд. 85 арк.

40 Звіт про діяльність НВIMУ за 2011 рік. 2011 р. Архів НВIMУ. Київ. Док. фонд. 69 с.

${ }^{41}$ Перспективний План роботи НВІМУ та його філій на 2013 рік. 2013 р. Архів НВIMУ. Київ. Док. фонд. 67 арк.

${ }^{42}$ Міненко Л. Віктор Карпов - організатор першого військово-історичного музею Збройних Сил України. Воєнно-історичний вісник. 2017. № 4(26). C. 69-78. 
set of thematic patriotic posters in a specialized cabinet for use in the educational process ${ }^{43}$.

\section{CONCLUSIONS}

In this study we reviewed the stages of the life cycle of the NMMHU from 1995 to 2014, grouped the types of its activities and described the peculiarities of the functioning of the department of stock work as an instrument for the formation of an integral part of Ukrainian cultural and historical heritage. Summarizing the aforementioned, it can be concluded that the National museum of military history of Ukraine, thanks to the professional efforts of its head Doctor of Historical Sciences, Colonel V. Karpov and the chief custodian of the stocks, Doctor of Cultural Studies, Z. Denysiuk for the period under study became a powerful cultural and educational, scientific and research institution. The efforts of participants in this process created a systemic basis for the sustainable development of the Main Museum of the Armed Forces of Ukraine and its branches. The established rules influenced the organization and activity of museum formations in military units, military educational institutions and organizations. With the help of professional regular planning and methodological support of work of the military museums of the AFU by 2013 it became possible to properly preserve the military-historical heritage of the Ukrainian people by museum means, coverage of the heroic struggle of the Ukrainian people for independence and the status of the national army in conditions of different historical periods. From the middle of 2013 to the present day the museum is in a state of uncertain transformation processes. This uncertainty, in our opinion, is the reason for the aging of the NMMHU, which is directly related to the leveling of the place and role of the scientific department of the stock work and is the source of emergence of the threat of losing the status of "National".

\section{SUMMARY}

The formation of the Ukrainian cultural-historical heritage is our direct duty to the coming generations. This is especially significant in the period of the formation of a young independent state. No one and nothing should be perceived through historical subjectivity, ideological, religious and political expediency. Directly responsible for this are the staff of museum stocks. Purpose of work is a study of the peculiarities of managerial aspects of stock work on the example of the National museum of military history of Ukraine. Based on the analysis of the internal documentary sources of the museum

43 Скрябін О. Звіт ЦМЗСУ про діяльність у 2006 році. Військовий музей. 2007. № 8. C. 204-250. 
and published historiographical materials, for the first time, were determined the stages of the life cycle of the museum from 1995 to 2014. Argued that the museum, as a specific institution, which activity is directed at systematic, scientific and methodological functioning in order to form national dignity and patriotism, has passed the stages of origin, creation, growth, maturity. It is emphasized that from the middle of 2013 under the influence of transgression phenomena for the museum began the period of uncertain transformations, which lead to its aging. The types of activities of the NMMHU grouped in terms of certain stages of its life cycle and the basic place and role of the department of stock work at each of the analyzed stages of development were substantiated. The managerial aspects of the stock work directly at the NMMHU and in particular in the branches and other museums of the Armed Forces of Ukraine are revealed. Due to the professional efforts of the leadership and the staff of the museum during the investigated period became a powerful cultural, educational, scientific and research institution. The efforts of participants in this process created a systemic basis for the sustainable development of the Main Museum of the Armed Forces of Ukraine and its branches.

\section{REFERENCES}

1. Бутко Т. Аспекти пошукової роботи ЦМЗСУ. Український військовий музей. 2009. № 1. С. 28-30.

2. Давидюк В. Основні напрями науково-фондової роботи ЦМЗСУ 3 комплектування музейного зібрання. Військовий музей. 2007. № 8. C. $183-189$.

3. Денисюк Ж. Комплектування фондів військового музею. Військовий музей. 2004. № 5. С. 251-257.

4. Денисюк Ж. Комплектування фондів та наукові дослідження музейних предметів. Украӥнський військовий музей. 2009. № 1. С. 23-27.

5. Денисюк Ж. Музейний предмет як джерело військової історії. Украӥнський військовий музей. 2010. № 2. С. 28-31.

6. Сфімова І. Виставка «Солдат і зброя». Військово-історичний альманах. 2007. № 1 (14). С. 159-160.

7. Звіт про діяльність Музею Збройних Сил України (МЗСУ) за 1997 рік. 1997 р. Архів НВIMУ (Архів Національного військовоісторичного музею України). Київ. Док. фонд. 3 арк.

8. Звіт про діяльність МЗСУ за 1998 рік. 1998 р. Архів НВIMУ. Київ. Док. фонд. 4 арк.

9. Звіт про діяльність Центрального музею Збройних Сил України (ЦМЗСУ) за 1999 рік. 1999 р. Архів НВIМУ. Київ. Док. фонд. 4 арк. 
10. Звіт про діяльність Національного військово-історичного музею України (НВIMУ) за 2010 рік. 2010 р. Архів НBIMУ. Київ. Док. фонд. 85 арк.

11.Звіт про діяльність НВIMУ за 2011 рік. 2011 р. Архів НВIMУ. Київ. Док. фонд. 69 с.

12. Звіт про діяльність НВIMУ за 2012 рік. 2012 р. Архів HВIMУ. Київ. Док. фонд. 55 с.

13. Звіт про діяльність НВIMУ за 2013 рік. 2013 р. Аpхів НВIMУ. Київ. Док. фонд. 113 с.

14. Карпов В. Музейна справа у Збройних Силах України (19962006). Київ : ЦМЗСУ ; МДФ «Українська хата», 2007. 96 с.

15. Карпов В. (відп. ред.). Виставка «Військова символіка України» в ЦМЗСУ. Військово-історичний альманах. 2007. № 2 (15), 1 обкл.

16. Карпов В. Діяльність ЦМЗСУ у 2000 році. Військовий музей. 2001. № 2. С. 90-101.

17. Карпов В. Діяльність ЦМЗСУ у 2002 році. Військовий музей. 2003. № 4. С. 105-120.

18. Карпов В. Діяльність ЦМЗСУ у 2003 році. Військовий музей. 2004. № 5. С. 179-200.

19. Міненко Л. Віктор Карпов - організатор першого військовоісторичного музею Збройних Сил України. Воєнно-історичний вісник. 2017. № 4(26). С. 69-78.

20. Монастирський Г. Теорія організації : підруч. Тернопіль : ТНЕУ, 2014. $288 \mathrm{c}$.

21. Небава М., Ратушняк О. Менеджмент організацій i адміністрування. Частина 1 : навчальний посібник. Вінниця : ВНТУ, 2012. $105 \mathrm{c}$.

22. Об инструкции по учету и хранению музейных ценностей из драгоценных металлов и драгоценных камней, находящихся в государственных музеях СССР : Приказ Министерства культуры CCCP от 15.12.1987 г. № 513. URL: http://ppt.ru/docs/prikaz/minkulturysssr/n-513-69255 (дата обращения: 26.12.2018 г.).

23. Про затвердження Положення про Музейний фонд України : Постанова Кабінету Міністрів України від 20.07.2000 р. № 1147. Дата оновлення: 23.03.2014. URL: http://zakon.rada.gov.ua/laws/show/1147$2000-\%$ D0\%BF (26.12.2018 p.)

24. Про затвердження Інструкції про порядок визначення оціночної та страхової вартості пам'яток Музейного фонду України : Наказ Міністерства культури і мистецтв України від 13.07.1998 р. № 325 . Дата оновлення: 17.10.2002 p. URL: http://zakon.rada.gov.ua/laws/show/ z0496-98 (дата звернення: 26.12.2018 р.). 
25. Про музеї та музейну справу : Закон України від 29.06.1995 № 249/95-BР. Дата оновлення: 02.10.2018. URL: http://zakon.rada.gov.ua/ laws/show/249/95-\%D0\%B2\%D1\%80 (дата звернення: 26.12.2018).

26. Про перейменування Центрального музею Збройних Сил України в Національний військово-історичний музей України та затвердження його Статуту : Наказ Міністерства оборони України від 16.07.2010 p. № 374. ГДАМОУ (Галуз. держ. архів Міністерства оборони України). Ф. 3697. Оп. 1П. Спр. 60. Арк. 59-76.

27. Протокол Науково-методичної ради НВIMУ щодо затвердження «Інструкції з музейного обліку, зберігання та використання пам'яток державної частини музейного фонду України». 29.09.2011 р. Аpхів НВIMУ. Київ. Док. фонд. 74 арк.

28. Перспективний План роботи НВІМУ та його філій на 2013 рік. 2013 р. Архів НВIМУ. Київ. Док. фонд. 67 арк.

29. Перспективний План роботи Центрального музею Збройних Сил України на 2000 рік. Архів НВIМУ. Док. фонд. 9 арк.

30. Руденко С. Грошова оцінка музейних предметів, що належать до зібрання НВІМУ. Український військовий музей. 2010. № 2. С. 11-14.

31. Седак Н., Денисюк Ж. Методика організації та проведення тематичних виставок у військово-історичному музеї (з практики роботи ЦМЗСУ). Військовий музей. 2001. № 2. С. 102-112.

32. Скрябін О. Звіт ЦМЗСУ про діяльність у 2004 році. Військовий музей. 2005. № 6. С. 159-187.

33. Скрябін О. Звіт ЦМЗСУ про діяльність у 2005 році. Військовий музей. 2006. № 7. С. 167-199.

34. Скрябін О. Звіт ЦМЗСУ про діяльність у 2006 році. Військовий музей. 2007. № 8. С. 204-250.

35. Тарасенко Л. Комплектування фондів - один із головних напрямів формування джерельної бази музею РВСП. Військовий музей. 2006. № 7. C. 161-166.

Information about authors: Minenko M. A., Doctor of Economic Sciences, Professor

Minenko L. M., Postgraduate National Academy of Managerial Staff of Culture and Arts 9, Lavrska str., Kyiv, Ukraine 